University of Nebraska - Lincoln

DigitalCommons@University of Nebraska - Lincoln

Entomology Papers from Other Sources

Entomology Collections, Miscellaneous

2009

Protein digestion in larvae of the red oak borer Enaphalodes

rufulus

Damon Crook

USDA APHIS PPQ, CPHST, Otis Laboratory, Massachusetts, U.S.A .

Sheila Prabhakar

Kansas State University, Manhattan, Kansas, U.S.A .

Brenda Oppert

USDA ARS

Follow this and additional works at: https://digitalcommons.unl.edu/entomologyother

Part of the Entomology Commons

Crook, Damon; Prabhakar, Sheila; and Oppert, Brenda, "Protein digestion in larvae of the red oak borer Enaphalodes rufulus" (2009). Entomology Papers from Other Sources. 47.

https://digitalcommons.unl.edu/entomologyother/47

This Article is brought to you for free and open access by the Entomology Collections, Miscellaneous at DigitalCommons@University of Nebraska - Lincoln. It has been accepted for inclusion in Entomology Papers from Other Sources by an authorized administrator of DigitalCommons@University of Nebraska - Lincoln. 


\title{
Protein digestion in larvae of the red oak borer Enaphalodes rufulus
}

\author{
D A MON J . CROOK ${ }^{1}$, S HEIL A PRAB HAKAR ${ }^{2}$ and \\ B R E N D A OP P R T ${ }^{3}$ \\ ${ }^{1}$ USDA APHIS PPQ, CPHST, Otis Laboratory, Massachusetts, U.S.A., ${ }^{2}$ Department of Entomology, \\ Kansas State University, Manhattan, Kansas, U.S.A. and ${ }^{3}$ USDA ARS Grain Marketing and Production Research Center, \\ Manhattan, Kansas, U.S.A.
}

\begin{abstract}
In the Ozark Mountains of the U.S.A., the red oak borer Enaphalodes rufulus contributes to the destruction of red oaks. To understand nutrient digestion in E. rufulus larvae, digestive proteinases are compared in both larvae fed heartwood phloem and those transferred to artificial diet. The $\mathrm{pH}$ of gut extracts is approximately 6.3 in the midgut and foregut and decreases to 5.5 in the hindgut region. The hydrolysis of casein by midgut extracts from E. rufulus larvae fed either artificial diet or phloem from tree sections increases in buffers greater than $\mathrm{pH} 6.19$, with maximum hydrolysis being observed at $\mathrm{pH}$ 10.1. Casein zymogram analysis reveals two major proteinase activities in larval midgut extracts of diet-fed larvae, with molecular masses of approximately 25 and $40-60 \mathrm{kDa}$, whereas phloem-fed larvae have proteinase activities corresponding to 40,45, 60, 80 and $>100 \mathrm{kDa}$. Substrate analysis indicates at least one major trypsin-like activity in both gut extracts with a molecular mass of $>100 \mathrm{kDa}$, but two chymotrypsin-like activities of approximately 25 and $>200 \mathrm{kDa}$ are found only in diet-fed larvae. Inhibitors of serine proteinases are most effective in reducing the general proteolytic activity of midgut extracts from larvae fed either food source. The data indicate that serine proteinase inhibitors have the potential to reduce E. rufulus larval damage to oaks. In particular, transgenic technologies incoporating trypsin inhibitors may be effective in reducing protein digestion in phloem-feeding larvae.
\end{abstract}

Key words. Cerambycidae, Coleoptera, Enaphalodes rufulus, longhorned beetle, Ozark Mountain red oak, proteinases; Quercus rubra.

\section{Introduction}

The red oak borer Enaphalodes rufulus (Haldeman) (Coleoptera: Cerambycidae), is a native longhorned beetle found in most regions of the eastern U.S.A. Historically, E. rufulus is a minor pest of oaks (Quercus spp.), although recent outbreaks of unprecedented magnitude are a major factor contributing to oak mortality within the forests of the Ozark Mountains in Arkansas, Oklahoma and Missouri (Stephen et al., 2001; Crook et al., 2004, 2007; Fierke et al., 2005a, b). Red oak (Quercus rubra) damage and mortality

Correspondence: Brenda Oppert, Grain Marketing and Production Research Center, 1515 College Avenue, Manhattan, KS 66502-2796, U.S.A. Tel.:+01 785776 2780; fax:+01 785537 5584; e-mail: bso@ksu.edu associated with this insect epidemic is dramatic and expensive (Stephen et al., 2001).

The beetle has a 2-year life cycle (Stephen et al., 2001; Fierke $e t$ al., 2005a) where synchronous emergence of adults occurs in odd-numbered years (Hay, 1972; Donley \& Acciavetti, 1980). The nocturnal adults live for approximately 3 weeks and do not feed on twigs or foliage (Solomon, 1995). Once mated, oviposition begins immediately (Donley, 1978) and continues for approximately 16 days. Each female oviposits approximately 120 eggs in bark crevices or under lichens (Donley, 1978). Eggs hatch within 10-13 days (Solomon, 1995) and larvae chew through the bark where they form a small gallery in the phloem tissue during the summer. After their first winter, larvae briefly resume feeding in the phloem before entering the heartwood, where they form long galleries. These second-year galleries result in 
severe timber degradation. Larvae overwinter in the heartwood gallery for the second year of their life cycle and they pupate in early May or June. Adult emergence begins in late May or June, depending on the latitude.

Studies on the red oak borer generally focus on general biology and life history (Hay, 1974; Donley \& Acciavetti, 1980; Solomon, 1995). More recent research deals with methods for sampling red oak borer 'within-tree' populations and quantifying the current outbreak (Crook et al., 2004, 2007; Fierke et al., 2005a, b). However, information on food digestion in wood-boring insects is scarce. The earliest report is a rudimentary study of digestive enzymes, including proteinases, in larvae of the Families Scolytidae, Cerambycidae, Lyctidae, Bostrychidae and Anobiidae (Parkin, 1940). Although cysteine proteinases are reported in a number of coleopteran insects, the phylogenetic distribution of cysteine proteinases in beetles suggests that they first appear in an early cucujiform ancestor (Cerambycidae) (Johnson \& Rabosky, 2000). Three species of Ceramabycids lack cysteine protienases, and it is hypothesized that cerambycids have retained a more ancestral serine (alkaline) digestive strategy (Johnson \& Rabosky, 2000). In larvae of the Asian longhorned beetle Anoplophora glabripennis, trypsinand chymotrypsin-like activities are reported (Bian et al., 1996). Serine and metallo proteinases, as well as leucyl aminopeptidase, are reported also in the crude midgut extract of another longhorned beetle, Morimus funereus larvae (Bozic et al., 2003).

The present study aims to understand protein digestion in damaging stages of E. rufulus. Therefore, digestive proteinases in the midgut of E. rufulus larvae from heartwood that were transferred to an artificial diet are compared with those of the phloem-feeding larval stage, using class-specific substrates and inhibitors. Gut $\mathrm{pH}$ values are estimated in diet-fed larvae to ascertain the relative activities of proteinases in different sections of the gut. This information identifies candidate proteins that may be incorporated into management strategies to prevent E. rufulus larval feeding and damage to oak trees.

\section{Materials and methods}

\section{Insects and dissections}

Heartwood-feeding E. rufulus larvae weighing $980 \pm 130 \mathrm{mg}$ $(n=5)$ were collected during March 2003 from red oak trees in the Ozark-St Francis National Forest, northeast Arkansas (Fig. 1A). Larvae were transferred to an artificial diet (cerambycid stem borer diet; Bio-Serv, Frenchtown, NJ). Phloemfeeding larvae $(15 \pm 10 \mathrm{mg}, n=10)$ were obtained by artificially inserting newly-hatched larvae into phloem tissue of $0.5-\mathrm{m}$ red oak bolts in June, 2003. The cut ends of the bolts were sealed with paraffin wax to retain moisture and aid the development of larvae. Larvae were dissected out of the phloem tissue in October 2003.

The midguts from actively-feeding larvae were obtained (Fig. 1A). Insects were chilled on ice and dissected
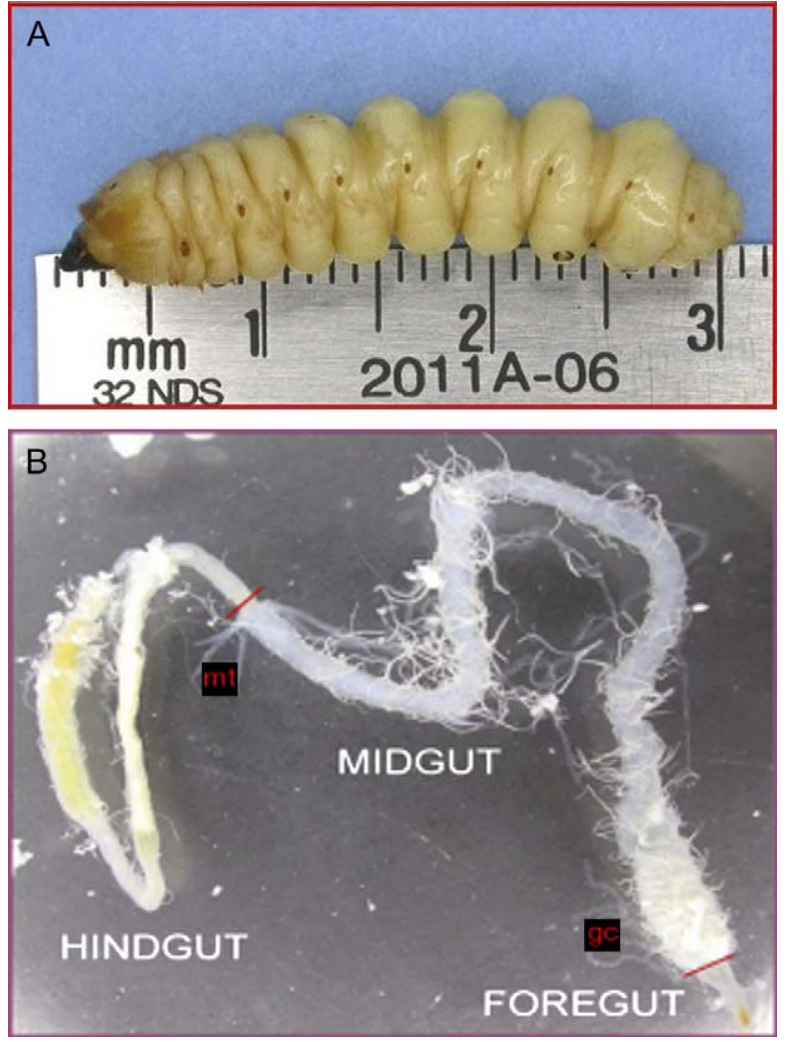

Fig. 1. (A) Second-year Enaphalodes rufulus larva from oak heartwood and transferred to artificial diet. (B) Dissected gut from dietfed E. rufulus larvae. Fore-, mid- and hindgut sections are denoted by red lines. GC, gastric cacae; MT, Malpighian tubulues.

longitudinally to expose their internal organs. The entire digestive tract was removed, cleaned of excess fatty tissue and placed in $50 \mu \mathrm{L}$ of distilled water. Midguts with contents were pooled, homogenized and centrifuged at $14000 \mathrm{~g}$ for 5 min, and the supernatant was removed and stored at $-20{ }^{\circ} \mathrm{C}$.

\section{Physiological and biochemical measurements}

To measure gut $\mathrm{pH}$, digestive tracts were removed from chilled insects, and the lumen contents of the different gut regions were extruded by applying pressure with the blunt end of forceps (Fig. 1B). The $\mathrm{pH}$ of this droplet was measured using a solid-state micro $\mathrm{pH}$ electrode with a tip diameter of $1 \mathrm{~mm}$ (Microelectrodes, Bedford, $\mathrm{NH}$ ).

To obtain a $\mathrm{pH}$ curve, the assay was modified from a previously published procedure (Oppert et al., 1997). Two microlitres of larval midgut extract containing 0.04 gut equivalents were diluted into buffers from $\mathrm{pH} 2-11$ using universal buffers (Frugoni, 1957). Buffers of different $\mathrm{pH}$ values were made using varying volumes of stock solution (54 $\mathrm{mL}$ of phosphoric acid, $45.8 \mathrm{~mL}$ of acetic acid, $49.6 \mathrm{~g}$ of boric acid), $2 \mathrm{~N}$ sodium hydroxide, water and solid potassium chloride to achieve the desired $\mathrm{pH}$. In a black 96-well 
microplate, $88 \mu \mathrm{L}$ of buffer with increasing $\mathrm{pH}$ was added to each row from left to right, and $2 \mu \mathrm{L}$ of gut extract was added to each buffer in the first four rows. To determine nonenzymatic hydrolysis of the substrate, $2 \mu \mathrm{L}$ of water was added to two additional rows. Ten microlitres containing 0.1 $\mu \mathrm{g}$ of a photosensitive general proteinase substrate, fluorescently-labelled casein, (BODIPY TR-X; Molecular Probes, Eugene, OR), was added in low light to all wells, and the plate was covered with foil. To evaluate the effects of reducing reagents on enzyme activity, $5 \mathrm{~mm} \mathrm{~L}$-cysteine was preincubated at $30{ }^{\circ} \mathrm{C}$ for 15 min with gut extracts in different $\mathrm{pH}$ buffers before addition of the substrate. Incubations with substrates were performed at $30{ }^{\circ} \mathrm{C}$, and activity was measured by the increase in fluorescence (excitation $584 \mathrm{~nm}$, emission $620 \mathrm{~nm}$ ).

A microplate assay (Oppert et al., 1997) was used to evaluate the effects of different inhibitors on enzyme activity in the crude midgut extract of E. rufulus larvae. Protein extract containing 0.04 larval gut equivalents was incubated with inhibitors for $15 \mathrm{~min}$ in universal buffer, $\mathrm{pH} 9.20$, at $30{ }^{\circ} \mathrm{C}$, with or without $5 \mathrm{~mm} \mathrm{L-cysteine} \mathrm{(Frugoni,} \mathrm{1957).} \mathrm{This} \mathrm{buffer}$ was chosen as a compromise because it would not adversely affect inhibitor stability, but would allow inhibitor effects on enzyme activity to be detected. The effect of inhibitors on the activity of enzymes in gut extracts also was measured using fluorescently-labelled casein, (BODIPY TR-X). Protease inhibitors included: aprotinin, chymostatin, transepoxysuccinyl-L-leucylamido[4-guanidino]butane (E-64), ethylenediamine tetraacetic acid (EDTA), leupeptin, pepstatin, phenylmethyl sulfonyl fluoride (PMSF), L-1-chloro-3[4-tosyl-amido]-7 amino-2 heptanone-hydrochloride (TLCK), L-1-chloro-3-(4 tosyl amido)-4 phenyl-2-butanone (TPCK) and soybean Bowman-Birk trypsin-chymotrypsin inhibitor (SBTI) (Boehringer Mannheim, Indianapolis, IN and Sigma Chemical Co., St Louis, MO). Inhibition of caesinolytic activity was calculated as a percentage of the control activity in the absence of inhibitors.

An activity blot assay of E. rufulus larval midgut extracts was performed as previously described (Oppert \& Kramer, 1998). Briefly, soluble midgut extracts were subjected to sodium dodecyl sulphate (SDS) polyacrylamide gel electrophoresis (Laemmli, 1970), using precast 10-20\% Tricine gels and Tricine SDS sample and running buffers (Invitrogen, Carlsbad, CA). After electrophoresis and electroblotting, nitrocellulose blots were incubated with a substrate solution ( $\alpha$-benzoyl-L-arginine $p$-nitroanilide, BApNA, or $N$-succinyl-ala-ala-pro-phe $p$-nitroanilide; SAAPFpNA) at a concentration of $0.5 \mathrm{mg} \mathrm{mL}^{-1}$ in $0.1 \mathrm{M}$ Tris, $\mathrm{pH} 8.1,0.02 \mathrm{M} \mathrm{CaCl}_{2}$, by placing blots in a plastic tray and layering $5 \mathrm{~mL}$ of substrate solution directly over the blot. Blots were covered with a $2 \mathrm{~mm}$ thick plastic sheet cut to the inside dimensions of the tray and incubated at $37{ }^{\circ} \mathrm{C}$ until a faint yellow color appeared (after 15-30 min). Liberated nitroaniline was diazotized for visualization by subsequent incubations of 5 min each in $0.1 \%$ sodium nitrite in $1.0 \mathrm{M} \mathrm{HCl}, 0.5 \%$ ammonium sulphamate in $1.0 \mathrm{M}$ $\mathrm{HCl}$ and $0.05 \% \mathrm{~N}$-(1-naphthyl)-ethylenediamine in $47.5 \%$ ethanol. Membranes were placed on a plastic sheet in heat-sealed bags at $-20{ }^{\circ} \mathrm{C}$. All substrates and chemicals were obtained from Sigma.

In zymogram gels, proteinases are characterized as clear bands where the enzyme has digested the substrate contained in the gel, and the nondigested protein is stained with Coomassie blue to provide contrast. Precast zymogram gels containing prestained casein (ZBC casein; Invitrogen) were used to detect proteinase activity in E. rufulus larval midgut extracts. Lanes containing larval gut extract (two gut equivalents) and Tris-glycine SDS sample buffer were loaded next to a well containing molecular mass markers (Mark12; Invitrogen). Electrophoresis was with Tris-glycine SDS running buffer (Invitrogen) at $125 \mathrm{~V}$ for $90 \mathrm{~min}$. The gel was transferred to Triton $\times 100$ diluted $1: 100$ in water, with gentle agitation at room temperature for $30 \mathrm{~min}$. The gel was then incubated with universal buffer, $\mathrm{pH} 9.2$, to evaluate serine proteinase activity.

\section{Results}

\section{Measurement of gut $\mathrm{pH}$}

The average $\mathrm{pH}$ of diet-fed E. rufulus larval gut was measured in different sections of the gut (Fig. 1B). Measurements of gut $\mathrm{pH}$ indicated that the foregut and midgut were less acidic than the hindgut. In fore- and midgut extracts, the $\mathrm{pH}$ was approximately 6.3. However, in the hindgut region, the $\mathrm{pH}$ of extracts was approximately 5.5. These measurements were made in diet-fed larvae, and the same data could not be obtained in phloem-fed larvae due to their small size. To determine the relative activity of gut proteases would require more precise measurements of gut $\mathrm{pH}$ in different sections of the midgut of actively-feeding larvae from tree sections.

\section{Biochemical measurement of gut extracts}

To evaluate the relative activity of proteinases in the midgut of E. rufulus larvae fed either artificial diet or phloem, soluble gut extracts were obtained from each set of larvae and were incubated with a proteinase substrate (i.e. fluorescentlylabelled casein) in buffers of increasing pH values (Fig. 2). Enzymes in both extracts demonstrated an increase in activity in buffers of $\mathrm{pH} 6.2$ or greater. The relative increase was slightly more for extracts from diet-fed than phloem-fed larvae when incubated in buffers of $\mathrm{pH} 6.2-8.6$ and at $\mathrm{pH}$ 11.7. The maximum activity for enzymes from both extracts was in $\mathrm{pH}$ 10.1 buffer. The activity was reduced at all $\mathrm{pH}$ values when a reducing reagent was added to the buffers (data not shown). These data suggest that activity was due primarily to alkaline serine proteinases in both extracts.

A casein zymogram of larval extract from E. rufulus demonstrated two major proteinase activities, approximately 25 and $40-60 \mathrm{kDa}$, in midgut extracts from diet-fed larvae (Fig. 3A). However, the bands of activity were broad and diffuse and may indicate multiple proteinases in these regions. Zymogram analysis of the extract of phloem-fed 


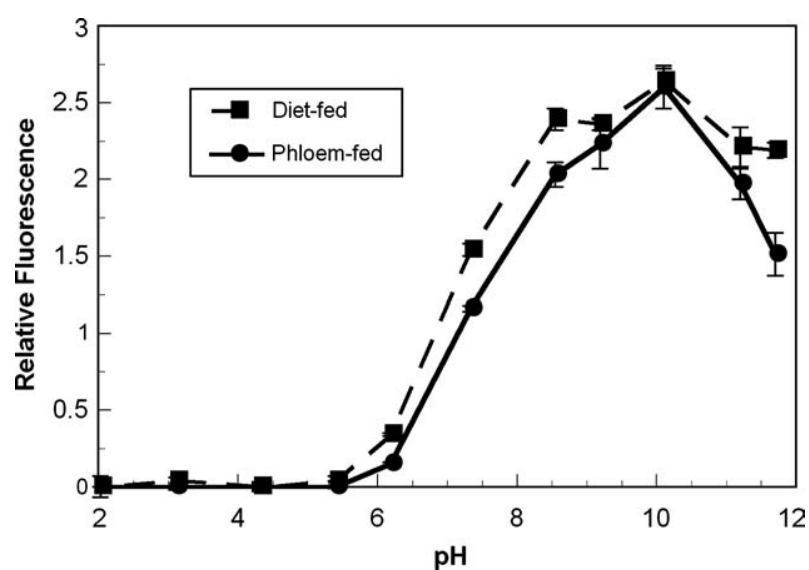

Fig.2. The hydrolysis of a general proteinase substrate, fluorescentlylabelled casein, by midgut extracts from Enaphalodes rufulus larvae, fed either artificial diet or phloem. Hydrolysis was measured in buffers of increasing $\mathrm{pH}$ values.

larvae demonstrated at least five major proteinase activities with less overall activity than those from diet-fed larvae (Fig. 3B). In addition to proteinases of approximately 45 $\mathrm{kDa}$, similar to one group of activity from diet-fed larvae, phloem-fed larval extracts also had proteinase activities at approximately 60,80 and $>100 \mathrm{kDa}$. The relative intensity of proteinase activities were not affected by reducing buffers (data not shown).
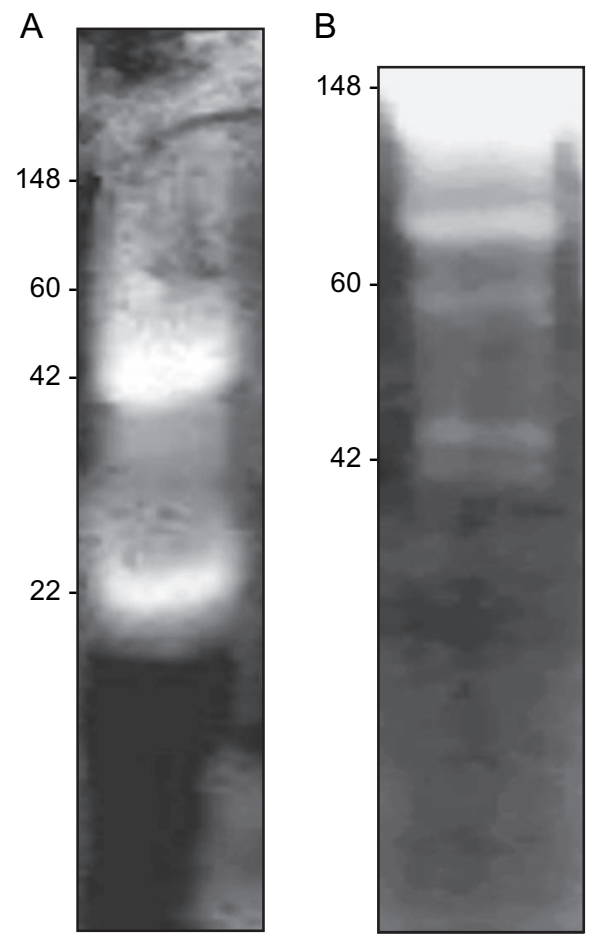

Fig. 3. Casein zymogram of larval midgut extract from Enaphalodes rufulus. (A) Diet-fed larvae. (B) Phloem-fed larvae.
Enaphalodes rufulus midgut proteinases were also evaluated by activity blot analysis (Fig. 4). After transfer, electroblotted enzymes were incubated with a trypsin substrate, BApNA (lanes 1 and 3) or a chymotrypsin substrate, SAAPFpNA (lane 2). A large molecular mass proteinase $(>100 \mathrm{kDa})$ with trypsin-like activity was found in extracts from both diet- and phloem-fed larvae (lanes 1 and 3). In diet-fed larvae, proteinases with molecular masses of 25 and $>200 \mathrm{kDa}$ (not entering the stacking gel) were identified as chymotrypsin-like activities, but, based on the amount of nitroaniline released, were relatively less active than the trypsin-like activity (lane 2). Chymotrypsin-like activity was not detectable in extracts from phloem-fed larvae. These data indicate that serine proteinase activity was present in extracts from both diet-fed and phloem-feeding larvae, and suggest that trypsin-like enzymes may account for more of the activity as well as play a more important role in tree-feeding larvae.

The in vitro effect of proteinase inhibitors on the caseinolytic activity of extract from diet-fed E. rufulus larvae was measured in $\mathrm{pH} 9.2$ buffer with or without reducing reagent, and in phloem-fed larvae in nonreducing buffer (Fig. 5). In nonreducing buffer, serine protease inhibitors, such as SBTI, TLCK, TPCK, PMSF and chymostatin, reduced the proteolytic activity of enzymes in diet-fed extracts by more than $50 \%$. However, in reducing buffer, TPCK, which is more specific for chymotrypsin, was no longer effective, and the inhibition by PMSF and chymostatin was greatly reduced. These data suggest that, in reducing conditions, enzymes from diet-fed larvae are more sensitive to trypsin than chymotrypsin

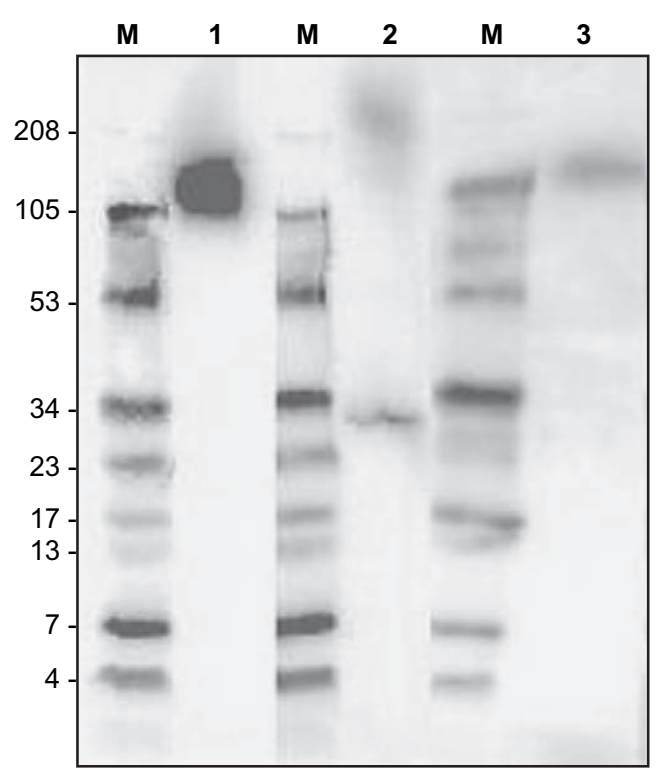

Fig. 4. Enaphalodes rufulus larval midgut proteinases from diet-fed $(1,2)$ or phloem-fed $(3)$ larvae, subjected to electrophoresis, transferred to nitrocellulose, and incubated with $(1,3)$ the trypsin substrate $\alpha$-benzoyl-L-arginine $p$-nitroanilide (BapNA) or (2) the chymotrypsin substrate $N$-succinyl-ala-ala-pro-phe $p$-nitroanilide (SAAPFpNA). M, molecular mass markers.

Journal compilation (C) 2009 The Royal Entomological Society, Physiological Entomology, 34, 152-157

No claim to original US government works 


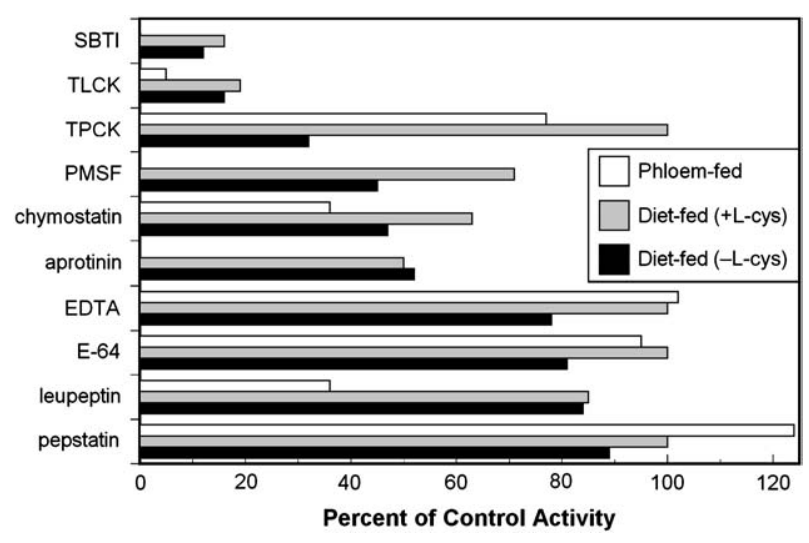

Fig. 5. Effect of proteinase inhibitors on the in vitro activity of Enaphalodes rufulus midgut extract from diet-fed larvae (under reducing or nonreducing buffer) or phloem-fed larvae (nonreducing buffer only) using fluorescently-labelled casein (BODIPY TR-X) as a general proteinase substrate.

inhibitors and may indicate that E. rufulus chymotrypsin is unstable under reducing conditions. SBTI, PMSF and aprotinin completely inhibited the proteinase activity in extracts from phloem-fed larvae. TLCK treatment of the extract resulted in more than $90 \%$ reduction in activity. These data indicate that trypsin inhibitors may be effective in reducing damage by this larval stage. In addition, chymostatin and leupeptin reduced proteolytic activity by $64 \%$ and TPCK reduced the activity by $23 \%$, indicating that chymotrypsin inhibitors may be partially effective in phloem-feeders. E-64, which targets primarily cysteine proteinases that are more active in reducing buffers, only slightly reduced activity in either extract. However, although a $20 \%$ reduction in enzyme activity in diet-fed larvae was achieved by incubating the extract with E-64 in nonreducing buffer, there was no inhibition of activity in reducing buffer. In nonreducing buffer, pepstatin, which is an inhibitor of aspartic proteinases, and EDTA, which is an inhibitor of metalloproteinases, caused an $11 \%$ and $22 \%$ reduction in enzyme activity, respectively, from diet-fed larval extracts, but no inhibition of enzymes in phloem-fed extracts. These inhibitors were ineffective in reducing the activity of diet-fed larval enzymes in reducing buffers.

\section{Discussion}

The overall analysis of the total midgut proteolytic activity in E. rufulus using buffers of increasing $\mathrm{pH}$ indicates that digestive proteinases from either diet- or phloem-fed larvae have optimal activity in slightly acidic to alkaline $\mathrm{pH}$ buffers, and that the activity is reduced when reducing reagents are added to the buffers. Therefore, E. rufulus larvae have alkaline proteinases that are sensitive to strong reducing conditions. However, because cysteine proteinases can be unstable during assay conditions (buffer, temperature, time), it is not possible to preclude the presence of cysteine proteinases in the
E. rufulus gut. Indeed, the overall slightly acidic $\mathrm{pH}$ of the gut contents suggests that cysteine proteinase activity may be present but undetected in the present study. In another coleopteran, Tenebrio molitor, the $\mathrm{pH}$ from the anterior to posterior graduates from 5.2 to 8.2 , cysteine proteinase activity is compartmentalized to the anterior region of the larval midgut and serine proteinase activity is optimal in the posterior midgut (Thie \& Houseman, 1990; Terra \& Ferreira, 1994; Vinokurov et al., 2006). Compartmentalization of enzyme activity in the gut may explain the incongruency of low caseinolyitc activity of $E$. rufulus larval enzymes in gut extracts at $\mathrm{pH} 6.1$ (i.e. there may be localized areas of the E. rufulus gut in which the $\mathrm{pH}$ is more alkaline).

There are two major groups of proteinase activities in extracts from diet-fed larvae based on gel migration, and at least five distinct activities are discernible in extracts from phloem-fed larvae. These activities are due to trypsin-like enzymes in both extracts and chymotrypsin-like activities in extracts from diet-fed larvae. Differences in enzymes in the two extracts may relate to enzyme stability or differences in food quality. Enzymes in phloem-fed larvae are more complex but less active, whereas fewer but more active proteinases in diet-fed larvae may be a reflection of the abundant single protein source in the artificial diet (i.e. casein).

Analysis of gut extracts with inhibitors suggests that effective inhibitors of gut proteinase activity from either diet- or phloem-fed larvae are those that target serine proteinases. Inhibitors of trypsin are more effective than chymotrypsin inhibitors in reducing the proteolytic activity of midgut enzymes in diet-fed larvae. Trypsin inhibitors completely inhibit the proteolytic activity of extracts from phloem-feeders, and therefore these inhibitors may be useful in reducing tree damage by the more harmful developmental stage.

Current methods of genetic manipulation and biotechnology provide new tools to directly transfer genes encoding insect-pest resistance factors into trees. A gene encoding a protein similar to soybean trypsin inhibitor in poplar is wound inducible (Hollick \& Gordon, 1995), suggesting that native proteinase inhibitor genes in trees may be manipulated for increased expression and improved varieties for pest resistance. Identification of proteins that disrupt the activity of digestive enzymes of oak pests may lead to the development of oak cultivars with resistance to trunk and branch borers, using either exogenous gene expression via plant transformation, or selective breeding for resistance traits.

Severe heartwood degradation could theoretically be prevented if digestion could be disrupted to such an extent that E. rufulus are unable to survive their first-year larval overwintering period in the phloem tissue. Ideally, proteinase inhibitors should inhibit the digestion of the early-instar larvae that feed within the phloem tissue. The results obtained in the present study suggest that the efficacy of serine proteinase inhibitors, particularly trypsin inhibitors such as those from soybean, should be determined in bioassays with phloem-fed larvae to provide information on the feasibility of the future development of oaks with increase expression of proteinase inhibitors. These studies are recommended because insects can adapt to inhibitors, and bioassays will 
determine whether E. rufulus larvae can survive proteinase inhibitors through adaptive responses.

\section{Acknowledgements}

We thank Yoonseong Park and Leah Bauer for their helpful comments on the manuscript. Specimens are Voucher Number 193, deposited in the Kansas State University Museum of Entomological and Prairie Arthropod Research (KSU-MEPAR). Mention of trade names or commercial products in this publication is solely for the purpose of providing specific information and does not imply recommendation or endorsement by the U.S. Department of Agriculture. This is contribution \#07-277-J from the Kansas Agricultural Experiment Station.

\section{References}

Bian, X., Shaw, B.D., Han, Y. \& Christeller, J.T. (1996) Midgut proteinase activities in larvae of Anoplophora glabripennis (Coleoptera: Cerambycidae) and their interaction with proteinase inhibitors. Archives of Insect Biochemistry and Physiology, 31, 23-37.

Bozic, N., Vujcic, Z., Nenadovic, V. \& Ivanovic, J. (2003) Partial purification and characterization of midgut leucyl aminopeptidase of Morimus funereus (Coleoptera: Cerambycidae) larvae. Comparative Biochemistry and Physiology Part B. Biochemistry and Molecular Biology, 134B, 231-241.

Crook, D.J., Stephen, F.M., Fierke, M.K. et al. (2004) Biology and sampling of red oak borer populations in the Ozark mountains of Arkansas. Upland Oak Ecology. A Symposium: History, Current Conditions, and Sustainability. Gen. Tech. Rep. SRS-73 (ed. by M. A. Spetich), pp. 223-228. U.S. Department of Agriculture, Forest Service, Southern Research Station, Asheville, NC.

Crook, D.J., Fierke, M.K., Mauromoustakos, A. et al. (2007) Optimization of sampling methods for within-tree populations of red oak borer, Enaphalodes rufulus (Haldeman) (Coleoptera: Cerambycidae). Environmental Entomology, 36, 589-594.

Donley, D.E. (1978) Oviposition by the red oak borer, Enaphalodes rufulus Coleoptera: Cerambycidae. Annals of the Entomology Society of America, 71, 496-498.

Donley, D.E. \& Acciavetti, R.E. (1980) Red oak borer. USDA Forest Service Forestry Instructional and Distribution Leaflet 163, 7.

Fierke, M.K., Kinney, D.L., Salisbury, V.B. et al. (2005a) Development and comparison of intensive and extensive sampling methods and preliminary within-tree population estimates of red oak borer (Coleoptera: Cerambycidae) in the Ozark Mountains of Arkansas. Environmental Entomology, 34, 184-192.

Fierke, M.K., Kinney, D.L., Salisbury, V.B. et al. (2005b) A rapid estimation procedure for within-tree populations of red oak borer (Coleoptera: Cerambycidae). Forest Ecology and Management, 215, 163-168.

Frugoni, J.A.C. (1957) Tampone universale di Britton e Robinson a forza ionica costante. Gazetta Chimica Italiana, 87, 403-407.

Hay, C.J. (1972) Woodpecker predation on red oak borer in black, scarlet, and northern red oak. Annals of the Entomological Society of America, 65, 1421-1423.

Hay, C.J. (1974) Survival and mortality of red oak borer larvae on black, scarlet, and northern red oak in eastern Kentucky. Annals of the Entomological Society of America, 67, 981-986.

Hollick, J.B. \& Gordon, M.P. (1995) Transgenic analysis of a hybrid poplar wound-inducible promoter reveals developmental patterns of expression similar to that of storage protein genes. Plant Physiology, 109, 73-85.

Johnson, K.S. \& Rabosky, D. (2000) Phylogenetic distribution of cysteine proteinases in beetles: evidence for an evolutionary shift to an alkaline digestive strategy in Cerambycidae. Comparative Biochemistry and Physiology Part B. Biochemistry and Molecular Biology, 126B, 609-619.

Laemmli, U.K. (1970) Cleavage of structural proteins during the assembly of the head of bacteriophage T4. Nature, 227, 680-685.

Oppert, B. \& Kramer, K.J. (1998) Economical proteinase activity blot. American Biotechnology Laboratory, 16, 20.

Oppert, B., Kramer, K.J., \& McGaughey, W.H. (1997) Rapid microplate assay of proteinase mixtures. BioTechniques, 23, 70-72.

Parkin, E.A. (1940) The digestive enzymes of some wood-boring beetle larvae. Journal of Experimental Biology, 17, 364-377.

Solomon, J.D. (1995) Guide to Insect Borers in North American Broadleaf Trees and Shrubs. USDA Forest Service, Washington, DC.

Stephen, F.M., Salisbury, V.B. \& Oliveria, F.L. (2001) Red oak borer, Enaphalodes rufulus (Coleoptera: Cerambycidae), in the Ozark Mountains of Arkansas, U.S.A: an unexpected and remarkable forest disturbance. Integrated Pest Management Reviews, 6, 247-252.

Terra, W.R. \& Ferreira, C. (1994) Insect digestive enzymes: properties, compartmentalization and function. Comparative Biochemistry and Physiology Part B. Biochemistry and Molecular Biology, 109B, 1-62.

Thie, N.M.R. \& Houseman, J.G. (1990) Cysteine and serine proteolytic activities in larval midgut of yellow mealworm, Tenebrio molitor L. (Coleoptera: Tenebrionidae). Insect Biochemistry, 20, 741-744.

Vinokurov, K.S., Elpidina, E.N., Oppert, B. et al. (2006) Diversity of digestive proteinases in Tenebrio molitor (Coleoptera: Tenebrionidae) larvae. Comparative Biochemistry and Physiology, 145B, 126-137.

Accepted 18 November 2008

First published online 2 April 2009 